Revue bibliographique pour le domaine irano-aryen

\title{
Maria Subtelny. "Kāshifī’s Asrār-i qāsimī: A Late Timurid Manual of the Occult Sciences and Its Safavid Afterlife"
}

\section{Živa Vesel}

\section{(2) OpenEdition}

Journals

Édition électronique

URL : https://journals.openedition.org/abstractairanica/54336

DOI : 10.4000/abstractairanica.54336

ISSN : 1961-960X

Éditeur :

CNRS (UMR 7528 Mondes iraniens et indiens), Éditions de l'IFRI

\section{Référence électronique}

Živa Vesel, « Maria Subtelny. "Kāshifís Asrār-i qāsimī: A Late Timurid Manual of the Occult Sciences and Its Safavid Afterlife" », Abstracta Iranica [En ligne], Volume 42-43| 2021, document 8, mis en ligne le 30 décembre 2021, consulté le 18 décembre 2022. URL : http://journals.openedition.org/ abstractairanica/54336 ; DOI : https://doi.org/10.4000/abstractairanica.54336

Ce document a été généré automatiquement le 18 décembre 2022.

Tous droits réservés 


\title{
Maria Subtelny. “Kāshifī’s Asrār-i qāsimī: A Late Timurid Manual of the Occult Sciences and Its Safavid Afterlife"
}

\author{
Živa Vesel
}

\section{RÉFÉRENCE}

Maria Subtelny. "Kāshifi’'s Asrār-i qāsimī: A Late Timurid Manual of the Occult Sciences and Its Safavid Afterlife" in L. Saif, F. Leoni, M. Melvin-Koushki, F. Yahya (eds.).

Islamicate Occult Sciences in Theory and Practice. Leiden/Boston: Brill, 2020, p. 267-313.

1 Kamāl al-dīn Ḥusayn b. 'Alī Vā'ez-e Kāshefĩ (m. 910/1504-5), prédicateur et grand lettré d'époque timouride, compte parmi ses œuvres également un traité de magie, Asrār-e Qāsemī (Les secrets de Qāsem), rédigé en 907/1501-2. Telle qu'elle nous est parvenue, cette œuvre est fondée en particulier sur deux traités arabes, Kitāb 'uyūn al-ḥaqā’iq wa ị̣āh al-țarā’iq d'Abū al-Qāsem Aḥmad al-Sīmāwī et Siḥr al-'uyūn (Kitāb-e Ibn-i Ḥallāj) d'Abū 'Abdallāh Maghrebī, et contient la description de cinq sciences formant l'anagramme kulluhu-sirr: kīmiyā, līmiyā, hīmiyā, sīmiyā et rīmiyā. En dehors de l'alchimie, -la science la plus spirituelle d'après Kāshefī -, il s'agit dans l'ensemble de la description des pratiques de magie de différentes sortes où la place de choix revient à la conjuration des esprits, y compris selon la magie astrale. On trouve parmi les autorités citées notamment Ṭomțom Hendī, personnage encore non-identifié à qui on doit par ailleurs la description des images des trois cent soixante degrés de l'écliptique utilisées en magie.

2 Si l'appartenance éventuelle de Kāshefī au shiisme, par ses origines, n'est pas prouvée puisqu'il a vécu en milieu sunnite, son oeuvre est clairement alidophile et imamiste, ne serait-ce que par son Rowżat al-Shohadā'. Dans cet article exceptionnellement riche, 
l'auteur démontre que le fait de se réclamer seyyed et de la descendance de 'Alī, autorisait la rédaction des contenus de nature occulte et leur donnait un caractère universaliste. Ceci explique d'une part le choix du dédicataire, Qāsem-e Anvār (m. 837/1433), seyyed, maitre soufi charismatique et contesté, poète mystique et occultiste; et explique d'autre part, le fait que Asrār-e Qāsemī a connu une grande fortune sous les Safavides, dès le début par le résumé Toḥfe-ye Khānī dû au fils de Kāshefī, 'Alī Șafĩ en 928-9/1522-23, et particulièrement sous Shāh 'Abbās I où le texte a subi maintes interpolations.

\section{AUTEURS}

ŽIVA VESEL

CeRMI, CNRS, Paris 